\title{
IN SITU X-RAY FLUORESCENCE ANALYSIS OF ROCK ART PAINTINGS ALONG THE COAST AND VALLEYS OF THE ATACAMA DESERT, NORTHERN CHILE
}

\author{
MARCELA SEPÚLVEDA ${ }^{a *}$, SEBASTIAN GUTIERREZ ${ }^{a}$, JOSÉ CARCAMO ${ }^{a}$, ADRIAN OYANEDER ${ }^{a}$, DANIELA \\ VALENZUELA ${ }^{b}$, INDIRA MONTT ${ }^{c}$, AND CALOGERO M. SANTORO ${ }^{d, e}$
}

\author{
${ }^{a}$ Laboratorio de Análisis e Investigaciones Arqueométricas, Departamento de Antropología, Universidad de Tarapacá, Camino Azapa Km 12, Arica, Chile. \\ ${ }^{b}$ Departamento de Antropología, Universidad Alberto Hurtado, Almirante Barroso 10, CP 6500620, Santiago, Chile. \\ ${ }^{c}$ Instituto de Investigaciones Arqueológicas y Museo, Universidad Católica del Norte, calle Gustavo Le Paige s/n, San Pedro de Atacama, Chile. \\ ${ }^{d}$ Instituto de Alta Investigación, Universidad de Tarapacá, Antofagasta 1520, Arica, Chile. \\ ${ }^{e}$ Centro de Investigaciones del Hombre en el Desierto (CIHDE), Av. General Velásquez 1775, Edificio CIHDE, Arica, Chile.
}

\begin{abstract}
Results of exploratory in situ analyses with a portable X-Ray Fluorescence (XRF) applied to six rock painting sites, located from Lluta to Camarones coastal valleys in the Atacama Desert, northern Chile, are presented. The results indicate the use of iron oxide as a main component in all paintings, alone or combined with aluminum silicate. Arsenic, a component highly present in water in the region, was also identified, indicating the use of water as a possible binder or thinner. These output allow unraveling painting technology, a step forward to define and understand the stylistic variability of rock art (engravings and paintings) in the context of the social changes and continuities of prehistoric communities. Additionally, it illustrates the effectiveness of portable XRF, a non-destructive analytical tool, applied for the first time in the Atacama Desert.
\end{abstract}

\section{INTRODUCTION}

X-ray fluorescence (XRF) is one of the most common techniques applied in conservation and archaeology $y^{1-3}$, specially in Europe and the United States, because of its ability to identify the presence of elements in major and minor amounts, and its non-destructive and non-invasive method of application. The improvement of portable equipment has contributed over the last 40 years to increasing its use, as, in many cases, it allows in situ analysis without sample extraction. This technique is also valued for its relatively low cost and short period of analysis ${ }^{3}$. The use of portable instruments, such as Raman and especially X-ray fluorescence, has proven quite useful for the physicalchemical characterization of Paleolithic art and more recently for rock paintings by contributing to their preservation and preventing unnecessary sampling ${ }^{4-11}$.

In contrast, until recently, most of the work undertaken in Chile to identify paint components has involved invasive and destructive laboratory sample analysis methods, by means of X-ray diffraction ${ }^{12-14}$ or scanning electron microscope combined with energy dispersive X-ray spectroscopy ${ }^{15-19}$. Moreover, rock art paintings have been generally studied as images or iconographic representations, while the material aspects of these visual manifestations have been ignored because, among other issues, the lack of trained people in these methods and techniques, and the absence of specialized laboratories in Chile, of the kind where these samples were processed.

Paintings are embedded in complex production processes, from obtaining raw materials up to applying them onto a wall, followed by its subsequent use, maintenance, recycling, discarding or abandonment ${ }^{20-22}$. The selection or use of specific formulas in rock art painting can be as stylistic as the production of the images themselves. A figure is stylistic when it displays a selection of attributes of the real referent combined and arranged in a regular and specific way ${ }^{23}$. The composition of the panels, the use of certain techniques, and the selection of certain platforms or spaces can also reflect stylistic decisions. Thus, XRF analyses can help to find out whether dissimilar painting components or combinations of elements were used in rock art styles. In future research, we aim to strengthen the relation between physic and chemical results and cultural changes in the prehistory of northern Chile.

Along the coast and valleys of the Atacama Desert, in northern Chile, rock painting is a rare form of expression —only 8 sites have been identified to datewhich contrasts with the large number of engravings and geoglyphs recorded. These images were created during a wide temporal range, from the Formative period or "Andean Neolithic" time (ca. 2500 B.P) up to the beginning of the European colonial era (16th century $)^{24-25}$. The definition and understanding of the stylistic variability of rock art (engravings and paintings) in the context of the social changes and continuities in the study area has been recently addresed ${ }^{26}$. Thus the study of the composition of rock paintings is a different way to approach this thorny universal problem. Particularly, the stylistic and chronological framework for the Atacama Desert paintings continues to be uncertain, as most of the studies have concentrated on engravings and geoglyphs ${ }^{24-26}$. Besides, the motifs depicted in paintings are composed of geometric or indeterminate forms, making it difficult to compare them with iconography better chronologized, portrayed by means of other techniques and in different media (textiles, gourd pyro engraving, for example) ${ }^{27}$.

This study demonstrates the advantages of XRF portable instruments in determining the elemental characterization of rock paintings in the Atacama Desert, without destructive sampling. Also we contribute to paintings preservation.

\section{MATERIAL AND METHODS}

Six sites were analyzed, which included from north to south and from the Pacific Ocean inland: La Capilla-1 situated south of the mouth of the Azapa Valley; Vitor-3a located at the mouth of the Chaca valley (known as Caleta de Vitor); Ofragía-1 and Cruz del Siglo-1 located in the middle reaches of the Codpa Valley; Camarones-19 at the mouth of the valley of Camarones and Huancarane-1 in the middle reaches of this valley (Figure 1). These sites are spread over three of the four main valleys that traverse the Atacama Desert merging into the Pacific shore ${ }^{28}$. All painting rock art are in color red. All figures analyzed are generally small (up to $20 \mathrm{~cm}$ ). Only Huancarane and Ofragía 1 present two larger figures of ca. $50 \mathrm{~cm}$.

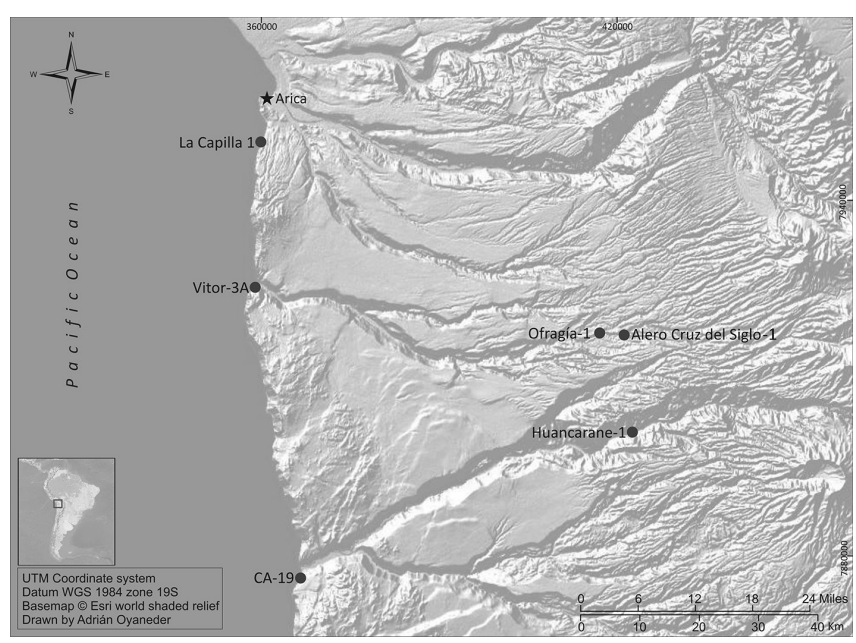

Figure 1. Map of rock art painting sites at northern Chile. 
Of the six sites, only La Capilla-1 (CAP-1) have been recently excavated and radiocarbon dated, placing its occupation at around 3500 B.P., contemporary with the transitional period between the Archaic (10500-3700 years, BP), embodied by hunter-gatherer-fishermen, and the Formative or Neolithic (37001500 years BP), which corresponds to sedentary farming groups ${ }^{29}$. New data, recently recorded, seem to indicate that CAP-1 cave and Vitor-3A were used late in the 19th century by Chinese slaves working in guano extraction. These operations, common along the South American Pacific the coast ${ }^{29}$, were carried by people brought from all over the Pacific, who replaced African farming slaves, whose condition was abolished throughout that century ${ }^{30}$

CAP-1 cave is one of the main sites on the coast with rock paintings. It is situated on a coastal promontory $20 \mathrm{~m}$ above the present-day mean sea level. The interior of the cave covers approximately $490 \mathrm{~m}^{2}$. The rock paintings are found only on the side walls adjacent to and facing the entrance that receive natural light. It contains 34 panels and 96 figures, $94 \%$ of which are geometric motifs, all made in red paint (Figure 2a ${ }^{28}$.
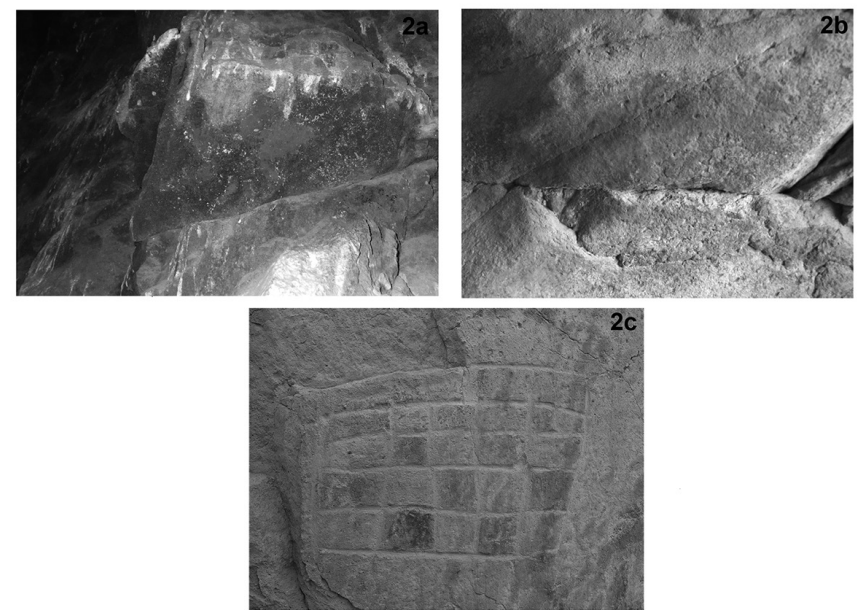

Figure 2. Analyzed examples of rock art painting. 2a) La Capilla 1.2. (CAP.1.2); 2b) Vitor-3a 3.6 (VIT. 3.6); 2c) Ofragía-1 1.2 (OFA 1.2).

Vítor-3a (VIT-3a) is a rock shelter also located on a coastal promontory, $15 \mathrm{~m}$ above the present tide line. The site is composed by three chambers covering approximately $30 \mathrm{~m}^{2}$, and contains 14 panels and 58 painted figures (Figure $2 \mathrm{~b}$ ). Of the total, $62 \%$ correspond to geometric motifs ${ }^{28}$.

Ofragía-1 (OFA-1) is located in the Codpa Valley, $59 \mathrm{~km}$ from the coast at 1768 masl. This rock art site, composed by 128 blocks and 338 panels, is situated strategically on the southern slope of the valley in an area associated with a major pre-Hispanic regional route ${ }^{25}$. Most of the figures are engraved, but one panel contains 2 painted figures and 1 figure that combine engraving and red painting.

Alero Cruz del Siglo-1 (CRU-1) is a small rock shelter of no more than $6 \mathrm{~m}^{2}$, located on the summit of a mountain, relatively away from other archeological contexts identified. The site contains 1 panel with 5 different geometric motifs: finger prints, vertical lines and one complex motif, of red color as in Ofragía-1.

The Camarones-19 (CA-19) site, at the mouth of this valley, is a rock shelter located $24 \mathrm{~m}$ above the present-day intertidal zone on a steep hillside that ends in a small bluff. The shelter covers $13 \mathrm{~m}^{2}$ and contains 16 panels with 15 figures, most of which are fingerprints of different sizes ${ }^{28}$. Most of the figures $(80 \%)$ are painted in red, and a small fraction in yellow, but only red paint samples were analyzed to keep a comparative sample with the other studied sites.

Huancarane-1 (HUA-1) is located in the Camarones Valley, $61 \mathrm{~km}$ from the coast and 1076 masl. It is situated on a fluvial terrace on the northern valley wall. The site is associated with a residential area and a local pathway, and contains 80 blocks with 207 panels. Most of the figures are engraved, but there is one panel containing a single red painting (Figure 2c).

XRF spectra were recorded with an XRF Bruker Tracer III-SD portable device with a detector fitted $10 \mathrm{~mm}^{2}$ XFlash ${ }^{\circledR}$ SDD, Peltier cooled and equipped with an X-ray tube $\mathrm{Rh}$ target; max voltage $40 \mathrm{kV}$. The specifications for this particular study were high voltage $15 \mathrm{kV}$ of energy, $21 \mu \mathrm{A}$ of intensity, an acquisition time of 30 seconds. We also use a vacuum pump (Figure 3). Data were collected and plotted using Tracer software S1PXRF 3.8.3. In total, 25 points were analyzed, 19 of which correspond to paintings and 6 to unmodified rock control sample (Table 1). All results obtained were semi- quantitative. The elements identified in the paintings were compared with the component identified from unmodified rock samples. For comparison all results were normalized as areas of each elements. Normalization was performed through the following formula: $\mathrm{N}=\mathrm{A} / \sum \mathrm{A}$, where $\mathrm{N}=$ Net Normalized, $\mathrm{A}=\mathrm{Net}$ and $\sum \mathrm{A}$ $=$ Sum of Net.

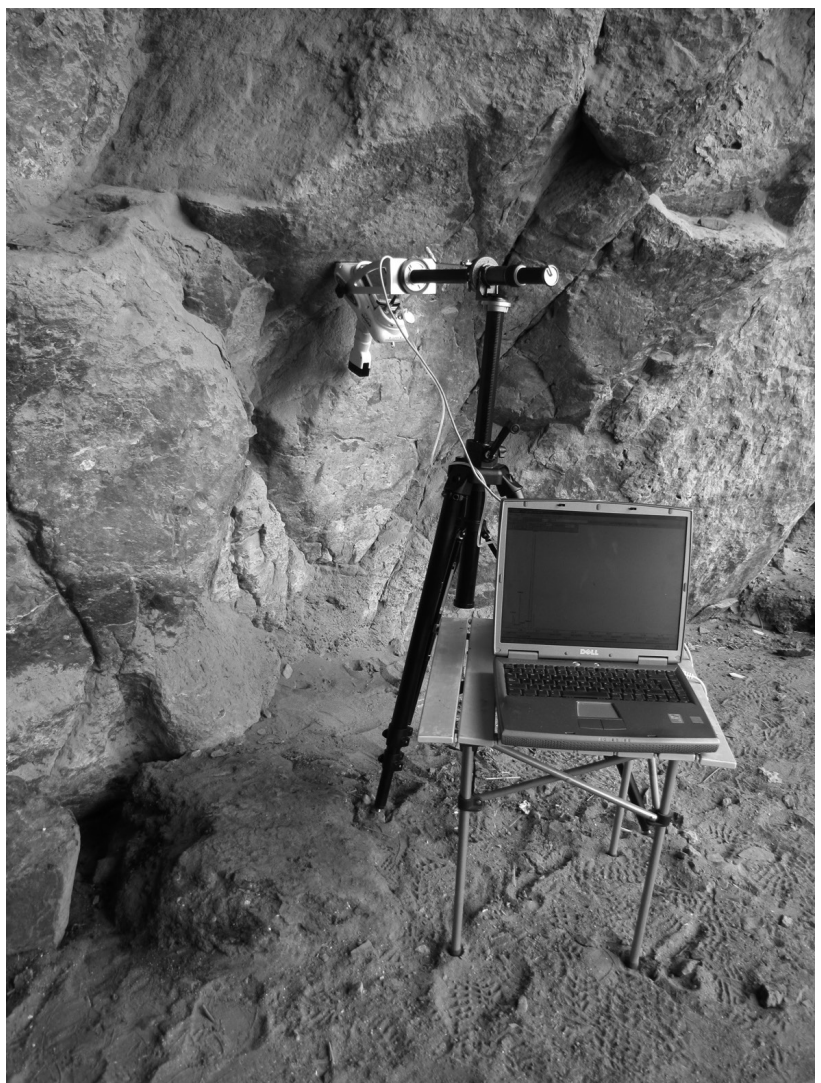

Figure 3. XRF portable at Vitor-3a.

\section{RESULTS AND DISCUSSION}

The most common and representative elements, $\mathrm{Al}, \mathrm{Si}, \mathrm{P}, \mathrm{S}, \mathrm{K}, \mathrm{Ca}, \mathrm{Ti}$, $\mathrm{Mn}, \mathrm{Fe}$, and As, for both paintings and rock platforms at the different sites studied (Table 1) are considered for discussion. First, one of the difficulties encountered was the presence of the same elements in the paintings and the unmodified rocks control sample, which make it difficult to differentiate the painting elements. Both samples display high levels of iron as well as calcium. The points analyzed display a high iron content ranging between 46 and $74 \%$. In the paintings, the identification of iron could be interpreted as the result of oxide used for pigment. As the unmodified rocks are entirely made of igneous ferromagnesian volcanic rock composed primarily of pyroclasts or ashes, they have a high iron content, between 37 and 64\%. However, arsenic, an element absent in the unmodified rock of the study sites, is present in combination with iron and another element (i.e. calcium).

\section{La Capilla-1}

The paintings reveal the predominance of iron, followed by calcium, which together account for approximately $80 \%$ of the elements identified (Table 1). The figure CAP 1.2 displays the highest iron content of all the paintings analyzed (Figure 4a). The paintings CAP 1.2 and 1.5 present arsenic as a trace element. The unmodified rock of these paintings shows higher presence of manganese, but in contrast it displays less sulfur and calcium than the paintings, except in the case of CAP 1.2. The other paintings, figure CAP 3.4, display high levels of aluminum and silica that may correspond to a mixture of some aluminum silicate with iron, which is different from iron-oxide-based paint. The presence of trace amounts of arsenic is notable in figure CAP-1 3.6 
Table 1. Normalized net areas of the elements detected by XRF portable. Results for pigments and unmodified rock at 6 six sites from Atacama Desert.

\begin{tabular}{|c|c|c|c|c|c|c|c|c|c|c|c|c|}
\hline Site & $\begin{array}{l}\text { Sample } \\
\text { Code }\end{array}$ & $\begin{array}{c}\text { Color or } \\
\text { Rock }\end{array}$ & $\mathrm{Al}$ & $\mathrm{Si}$ & $\mathrm{P}$ & $\mathrm{S}$ & K & $\mathrm{Ca}$ & $\mathrm{Ti}$ & $\mathrm{Mn}$ & $\mathrm{Fe}$ & As \\
\hline \multirow{6}{*}{ LA CAPILLA-1 } & CAP 1.1 & Red & 0.0054 & 0.0269 & 0.0069 & 0.0524 & 0.0160 & 0.2019 & 0.0198 & 0.0127 & 0.6161 & n.d. \\
\hline & CAP 1.2 & Red & 0.0036 & 0.0118 & 0.0041 & 0.0262 & 0.0155 & 0.1168 & 0.0177 & 0.0123 & 0.7456 & 0.0046 \\
\hline & CAP 1.3 & Red & 0.0055 & 0.0264 & 0.0095 & 0.0737 & 0.0191 & 0.2810 & 0.0218 & 0.0147 & 0.4955 & n.d. \\
\hline & CAP 1.4 & Red & 0.0043 & 0.0139 & 0.0084 & 0.0591 & 0.0177 & 0.2681 & 0.0190 & 0.0151 & 0.5459 & n.d. \\
\hline & CAP 1.5 & Red & 0.0041 & 0.0162 & 0.0070 & 0.0617 & 0.01599 & 0.2384 & 0.0184 & 0.0128 & 0.5585 & 0.0196 \\
\hline & CAP 1.6 & Rock & 0.0051 & 0.0324 & 0.0046 & 0.0326 & 0.0144 & 0.1317 & 0.0242 & 0.0604 & 0.6485 & n.d \\
\hline \multirow{7}{*}{ VITOR- 3A } & VIT 3.1 & Red & 0.0038 & 0.0105 & 0.0084 & 0.1133 & 0.0155 & 0.2967 & 0.0126 & 0.0115 & 0.5003 & n.d. \\
\hline & VIT 3.2 & Rock & 0.0038 & 0.0116 & 0.0084 & 0.1114 & 0.0152 & 0.2462 & 0.0204 & 0.0132 & 0.5294 & n.d. \\
\hline & VIT 3.3 & Red & 0.0046 & 0.0158 & 0.0084 & 0.0712 & 0.0111 & 0.1891 & 0.0262 & 0.0154 & 0.6117 & n.d. \\
\hline & VIT 3.4 & Red & 0.0610 & 0.0266 & 0.0088 & 0.0610 & 0.0107 & 0.1502 & 0.0269 & 0.0142 & 0.6550 & n.d. \\
\hline & VIT 3.6 & Red & 0.0052 & 0.0168 & 0.0195 & 0.1469 & 0.0144 & 0.4909 & 0.0077 & 0.0119 & 0.2392 & 0.0104 \\
\hline & VIT 3.7 & Red light & 0.0061 & 0.0249 & 0.0073 & 0.0710 & 0.0320 & 0.2084 & 0.0188 & 0.0151 & 0.5750 & n.d. \\
\hline & VIT 3.8 & Red & 0.0044 & 0.0099 & 0.0120 & 0.1701 & 0.0124 & 0.5121 & 0.0071 & 0.0103 & 0.2261 & n.d. \\
\hline \multirow{3}{*}{ OFRAGIA-1 } & OFA 1.1 & Red & 0.0066 & 0.0415 & 0.0035 & 0.0333 & 0.0291 & 0.0672 & 0.0131 & 0.0174 & 0.7297 & 0.0286 \\
\hline & OFA 1.2 & Red & 0.0089 & 0.0614 & 0.0044 & 0.0123 & 0.0587 & 0.0485 & 0.0205 & 0.0242 & 0.6972 & 0.0247 \\
\hline & OFA 1.3 & Rock & 0.0193 & 0.1676 & 0.0062 & 0.0093 & 0.0907 & 0.0525 & 0.0318 & 0.0359 & 0.4941 & n.d. \\
\hline \multirow{3}{*}{$\begin{array}{l}\text { CRUZ DEL } \\
\text { SIGLO-1 }\end{array}$} & CRU1.1 & Red & 0.0054 & 0.0232 & 0.0080 & 0.0712 & 0.0187 & 0.3047 & 0.0135 & 0.0157 & 0.4668 & 0.0292 \\
\hline & CRU 1.2 & Red & 0.0046 & 0.1920 & 0.0070 & 0.0790 & 0.0143 & 0.2844 & 0.0101 & 0.0128 & 0.5046 & 0.0327 \\
\hline & CRU 1.3 & Rock & 0.0152 & 0.1154 & 0.0100 & 0.0167 & 0.0958 & 0.0710 & 0.0434 & 0.0390 & 0.4544 & n.d. \\
\hline \multirow{3}{*}{ CAMARONES-19 } & CA.19.1.1 & Red & 0.0062 & 0.0373 & 0.0053 & 0.0320 & 0.0166 & 0.1087 & 0.0282 & 0.0251 & 0.6422 & 0.0096 \\
\hline & CA-19 1.2 & Red & 0.0045 & 0.0200 & 0.0078 & 0.0868 & 0.0138 & 0.2342 & 0.0163 & 0.0190 & 0.5051 & 0.0115 \\
\hline & CA-19 1.3 & Rock & 0.0058 & 0.0199 & 0.0114 & 0.0795 & 0.0169 & 0.3075 & 0.0257 & 0.0259 & 0.3725 & 0.0200 \\
\hline \multirow{3}{*}{ HUANCARANE-1 } & HUA 1.1 & Red & 0.0080 & 0.0486 & 0.0084 & 0.0970 & 0.0340 & 0.2844 & 0.0141 & 0.0154 & 0.4296 & 0.0235 \\
\hline & HUA 1.2 & Red & 0.0195 & 0.1572 & 0.0077 & 0.0121 & 0.1302 & 0.0663 & 0.0327 & 0.0534 & 0.3797 & 0.0263 \\
\hline & HUA 1.3 & Rock & 0.0143 & 0.0999 & 0.0096 & 0.0156 & 0.0899 & 0.0999 & 0.0421 & 0.0402 & 0.4266 & n.d. \\
\hline
\end{tabular}

\section{Vitor-3A}

The results do not clearly distinguish the paintings from the platform. The most prevalent element in figures VIT-3a 3.1, 3.3, 3.4 and 3.7 is iron (Table 1). In contrast, in figures VIT 3.6 and 3.8 the most prevalent element is calcium, with a lower iron content (less than $25 \%$ ), while unmodified rock contain $50 \%$ of iron in this site. We think that VIT 3.6 and Vitor 3.8 paint were not based on iron only, but rather possibly on aluminum silicate with presents iron content. These two figures also display, unlike the others, the presence of sulfur (Figure 4b). Taken together and by linear correlation, the presence of these two elements in these cases could indicate a mixture of calcium sulfate as gypsum, for example (Figure 5). The highest content of calcium compared with the lower amount of iron, seems to indicate that gypsum masked the reading of iron in the paintings.

\section{Ofragía -1}

The two points associated with paint (OFA 1.1 and 1.2) have high iron content and traces of arsenic, which allows the paint composition to be distinguished from that of the platform, in which that element is not identified (Figure 4c). Additionally, higher levels of aluminum and silica are observed on the platform (OFA 1.3) than in the paintings.

\section{Alero Cruz del Siglo-1}

The paintings and platform present similar quantities of iron (Table 1) Traces of arsenic were observed in the two paintings analyzed (CRU 1.1 and 1.2) but arsenic was absent on the unmodified rock (CRU 1.3). Two paintings contain higher levels of sulfur and calcium. As with Vitor-3a, these elements could indicate the formation of gypsum. On unmodified rock, higher levels of titanium and manganese were observed than in the paint that could be explained as trace elements typically found in rocks of the area. The presence of aluminum and silica are higher on the unmodified rock, with the exception of CRU 1.2, which show content of silica in the painting.

\section{Camarones 19}

The two paint points analyzed (CA-19 1.1 and 1.2) display higher levels of iron than on the unmodified rock (Table 1). Unlike previous sites, arsenic was identified both in the paint and the unmodified rock. The other elements appear in similar levels at all points analyzed.

Huancarane-1

Like Ofragía-1 and Cruz del Siglo-1, traces of arsenic were found only in the two paint points analyzed. Point HUA 1.2 also presents high levels of aluminum, silica, and potassium, as well as lesser amounts of iron in HUA 1.1 and 1.3, the latter on the platform (Table 1). Point HUA 1.1 displays a high level of calcium and sulfur possibly suggested to the formation of gypsum.

The results of in situ XRF analysis allowed us to define part of the chemical elemental characterization of rock paintings in the Atacama Desert, in northern Chile. The analyzed points display high iron content in both the raw material source of the pigment and in the unmodified rock control samples.

In all of the samples, traces of aluminum and silica are generally low. Based on these results we suggest that the analyzed paintings were made from some kind of iron oxide, possibly hematite. The exceptions are VIT 3.6 and VIT 3.8 that show low iron content in comparison to unmodified rock control samples (Table 1). Thus we suggest that the paintings of these points (VIT 3.6 and VIT 3.8) were based on other material, possibly aluminum silicate mixed with iron (Figure 6).

Sulfur and calcium proportions follow a linear correlation, which make us to suspect the formation of a gypsum coat. Patina composed by this kind of element has been identified over rock surface overlaying the paintings in samples stratigraphically analyzed from other regions of the Atacama Deser ${ }^{16}$. This type of chemical deposition is typical of this hyper-arid region due to rock weathering and groundwater remobilization ${ }^{31}$. 

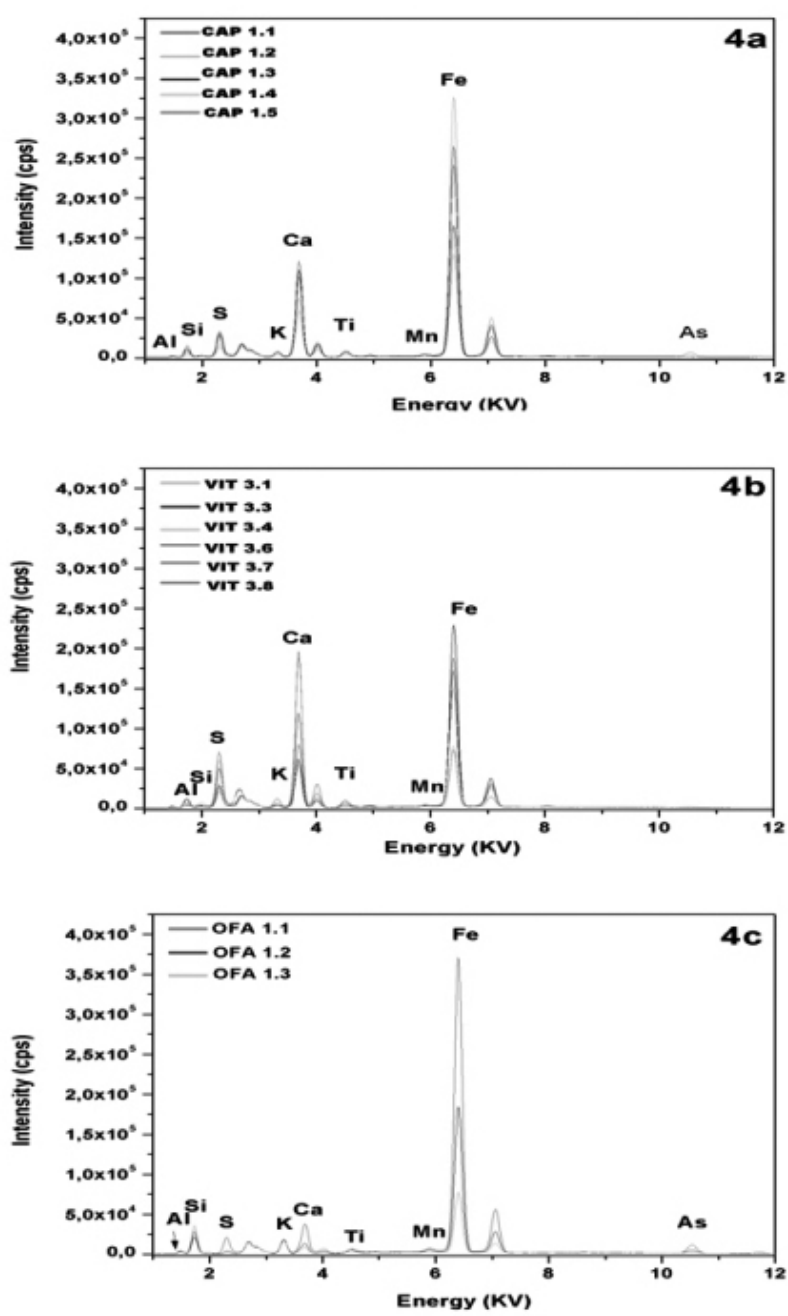

Figure 4. 4a) XRF spectrum of La Capilla-1 rock art painting; 4b) XRF spectrum of Vitor-3a rock art painting; 4c) XRF spectrum of Ofragía-1 rock art painting.

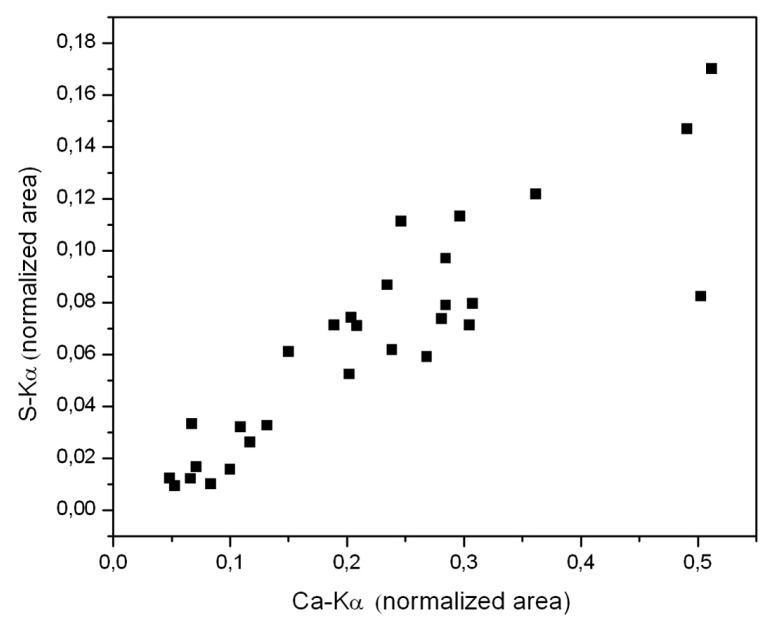

Figure 5. Comparison of $\mathrm{S}$ and $\mathrm{Ca}$ normalized net area of all analyzed points.

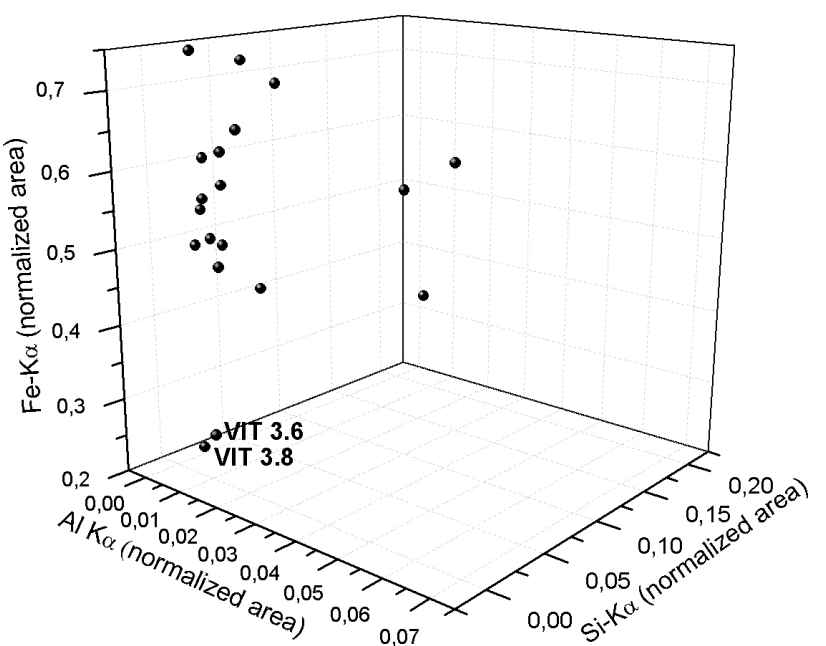

Figure 6. Comparison of $\mathrm{Al}, \mathrm{Si}$ and $\mathrm{Fe}$ normalized net area without unmodified rock.

The presence of arsenic traces in different sample of the analyzed paint points distinguish them from the unmodified rock control samples, which do not present this element, except in the case of Ca-19. Arsenic, a common element on watercourses in northern of Chile ${ }^{32}$, has already been identified in highland paintings of this region ${ }^{18}$. The high content of arsenic in rock paintings could indicate that technological formula to make the paints included the use of water as a binder or thinner. Some paintings, however, could have used resin, honey, egg or animal fat as binder or thinner, but we did not analyze this aspect here. We also do not know if this kind of organic compounds is preserved until now.

In relation to previous studies ${ }^{15-19}$, this work shows the importance of preliminary qualitative analysis of XRF portable technique. We can know effectively determine with better precision where to take samples for quantitative elemental analysis and for molecular characterization. Until recently, the first author of this work only used destructive analysis with no information of painting elemental composition. Thus, from a methodological perspective this innovative no destructive technique was first time applied in Chile in rock art paintings.

\section{CONCLUSION}

Iron oxide was the main component in all paintings applied alone or in combination with aluminum silicate. Besides, the presence of arsenic, a high component in the water of the rivers of the study area, suggests that water was possible used as binder or thinner. This formula was common to all the samples analyzed that cover a wide temporal and spatial range, but the implications in the context of the social changes and continuities of prehistory of northern Chile is still premature to be outlined. The results, however, provide information about painting technology, an important issue to understand the stylistic variability of rock art in the region. Finally, the first application of in situ XRF has opened new opportunities for studying rock art paintings in the Atacama Desert, and in Chile in general. It application has demonstrated that it helps to preserve these ancient and fragile rock art paintings.

\section{ACKNOWLEDGMENT}

Funding was provided by FONDECYT grant 1111063 . We acknowledge the ongoing support from MECESUP UTA 0801 and Convenio de Desempeño Universidad de Tarapacá-MINEDUC. We thank to Joan Donaghey and Carolina Santoro for English translation and editing and Dan Sandweiss for comments and further English editing.

\section{REFERENCES}

1.- $\quad$ M. Mantler, M. Schreiner, X-Ray Spectrometry, 29, 3, (2000).

2.- K. Janssens, G. Vittiglio, I. Deraedt, A. Arts, B. Vekemans, L. Vineze, F. Wei, I. Deryck, O. Schalm, f. Adams, A. Rindby, A. Knöchel, A. Simionovici, A. Snigirev, X-Ray Spectrometry, 29, 73, (2000).

3.- L. Moens, A. von Bohlen, P. Vandenabeele, in Modern Analytical Methods in Art and Archaeology, E. Ciliberto, G. Spoto eds. Wiley Sons, 
New York, 2000, Vol. 155; pp. 55-79.

4.- M. Rowe, in Handbook of Rock Art Research. Physical and chemical analysis, D. Whitley ed. Altamira Press, New York, 2001; pp. 190-220.

5.- $\quad$ B. Newman, L. Loendorf, Plains Anthropologist, 50, 277, (2005).

6.- A. Hernanz, J.F. Ruiz-López, J.M. Gavira Vallejo, S. Martín, E. Gavrilenko, Journal of Raman Spectroscopy, 41, 1104, (2010).

7.- C. Roldán, S. Murcia-Mascarós, J. Ferrero, V. Villaverde, E. López, I. Domingo, R. Martínez, P. M. Guillem, X-Ray Spectrometry, 39, 243 , (2009).

8.- A. Tournié, L. Prinsloo, C. Paris, P. Colomban, B. Smith, Journal of Raman Spectroscopy, 42, 399, (2010).

9.- M. J. Nuevo, A. Martín Sánchez, C. Oliveira, J. de Oliveira, X-Ray Spectrometry, 41, 1, (2012).

10.- J. Huntley, Australian Archaeology, 75, 78, (2012).

11.- S. Lahlil, M. Lebon, L. Beck, H. Rousselière, C. Vignaud, I. Reiche, M. Menu, P. Paillet, F. Plassard, Journal of Raman Spectroscopy, 43, 1637 , (2012).

12.- I. Wainwright, K. Helwig, M. M. Podestá, C. Bellelli, in Arte en las Rocas: Arte Rupestre, Menhires y Piedras de Colores en la Argentina, M. M. Podestá, M. De Hoyos eds. SAA y Asociación Amigos del INA, Buenos Aires, 2000; pp. 203-206.

13.- I. Wainwright, K. Helwig, D. Rolandi, C. Aschero, C. Gradin, M. M. Podestá, M. Onetto, C. Bellelli, in L'art Avant la Préhistoire. La Conservation de L'art Préhistorique, $10^{\circ}$ Journées D'études de la Section Française de l'Institut International de Conservation, Champs Sur Marne, 2002; pp. 15-24.

14.- H. Niemeyer, V. León, Arte Rupestre Precolombino en el Tinguiririca. Provincia de Colchagua, Sexta Región de Chile, Gráfica Escorpio, Santiago, 2001.

15.- M. Sepúlveda, E. Laval, in Actas del XVIII Congreso Nacional de Arqueología Chilena, Ediciones Kultrún-SCHA, Universidad Austral de Chile, Valdivia, 2010; pp. 825-834.

16.- M. Sepúlveda, E. Laval, in Actas del XVIII Congreso Nacional de Arqueología Chilena, Ediciones Kultrún-SCHA, Universided Austral de Chile, 2010; pp. 1111-1124.
17.- M. Sepúlveda, Magallania, 39, 193, (2011).

18.- M. Sepúlveda, E. Laval, L. Cornejo, J. Acarapi, Rock Art Research, 29, 93, (2012).

19.- M. Sepúlveda, D. Valenzuela, L. Cornejo, H. Lienqueo, H. Rousselière, Chungara Revista de Antropología Chilena, 45, 143, (2013).

20.- M. Schiffer, American Antiquity, 37, 156, (1972).

21.- C. Aschero, in Arqueología Contemporánea Argentina; Actualidad y Perspectiva, H. Yacobaccio, L. Borrero, L. C. García, G. Politis, C. Aschero, C. Bellelli eds. Ediciones Búsqueda, Buenos Aires, 1988; pp. 109-146.

22.- D. Fiore, Rock Art Research, 24, 149, (2007).

23.- W. Davis, in The use of style in archaeology: new directions in archaeology, M. Conkey, C. Hastorf eds. Cambridge University Press, Cambridge, 1190; pp. 18-31.

24.- L. Briones, Antiquity, 80, 9, (2006).

25.- I. Muñoz, L. Briones, Chungara, 28, 47, (1996).

26.- D. Valenzuela, M. Sepúlveda, C.M. Santoro, I. Montt, Interciencia 39, 444, (2014).

27.- C. M. Santoro, P. Dauelsberg, in Estudios en Arte Rupestre. Primeras Jornadas de Arte y Arqueología, C. Aldunate, J. Berenguer, V. Castro eds. Museo Chileno de Arte Precolombino, Santiago, 1985; pp. 69-86.

28.- A. Oyaneder, C. Alday, M. Sepúlveda, D. Valenzuela, Mundos de Antes, 8, (2014).

29.- L. Núñez, C. M. Santoro, Chungara Revista de Antropología Chilena, $\mathbf{4 3}$, 487, (2011).

30.- M. J. Gonzales, Journal of Latin American Studies, 21, 385, (2009).

31.- J. A. Rech, S. Pigati, J. Quade, J. L. Betancourt, Palaeogeography, Palaeoclimatology, Palaeoecology, 194, 207, (2003).

32.- J. Bundschuh, H. Nicolli, M. d. C. Blanco, M. Blarasin, S. Farías, L. Cumbal, L. Cornejo, J. Acarapi, H. Lienqueo, M. Arenas, R. Guérèquiz, P. Bhattacharya, M. E. García, J. Quintanilla, E. Deschamps, Z. Viola, M. L. C. d. Esparza, R. Rodríguez, A. P. Carrera, A. F. Cirelli, in IBEROARSEN. Distribución del Arsénico en las Regiones Ibérica e Iberoamericana, J. Bundschuh, A. P. Carrera, M. Litter eds. CYTED Ediciones, Buenos Aires, 2008; pp. 137-179. 